\title{
HUKUM WARIS ISLAM KONTEMPORER (PERSPEKTIF HERMENEUTIKA MUHAMMAD SYAHRÛR)
}

\author{
Khaerul Ardhian Syaekh ${ }^{凶}$ \\ Sekolah Tinggi Ilmu Fikih (STIF) Syeikh Nawawi Tanara Serang Banten - Indonesia
}

\begin{abstract}
Abstrak
Muhammad Syahrûr merupakan salah seorang intelektual muslim kontemporer yang menawarkan sebuah metodologi baru untuk menafsirkan, memahami dan menetapkan hukum-hukum dalam al-Qur'an. Dengan metodologi tersebut al-Qur'an yang rasional, sistematis, dan komprehensif bisa menjadi al-Qur'an salih li kulli zaman wa makan. Metodologi tersebut bisa dijadikan upaya untuk mendialogkan al-Qur'an dalam menjawab persoalan kekinian dan mampu mengakomodasi perubahan dan perkembangan zaman. Muhammad Syahrûr melakukan pembacaan ulang terhadap alQur'an dengan pendekatan hermeneutik yang didasarkan pada pendekatan linguistik yang ia sebut dengan manhaj al-tarikh. Dijadikannya pendekatan linguistik oleh Syahrûr sebagai metode al-Qur'an tak lepas dari asumsinya bahwa al-Qur'an memiliki dua sisi kemukjizatan yakni sastrawi dan ilmiah. Yang pertama dipahami dengan pendekatan deskriptif-signikatif sedangkan yang kedua dengan pendekatan historisilmiah yang keduanya terletak pada bingkai studi lingusitik. Dalam hal hukum waris Muhammad Syahrûr berpandangan mengapa dalam anggapan mufasir, laki-laki selalu mendapat dua kali lipat bagian perempuan, dan dianggap sebagai aksioma yang dibuktikan dengan argumen bahwa perempuan kurang akal dan agama.
\end{abstract}

Kata Kunci: hukum waris islam, kontemporer, hermeneutika

\begin{abstract}
Muhammad Syahrûr is one of the contemporary Muslim intellectuals who offers a new methodology for interpreting, understanding and establishing the laws in the Qur'an. With this methodology, a rational, systematic, and comprehensive al-Qur'an can become the salih li kulli al-Qur' an of the time of wa eating. This methodology can be used as an effort to have a dialogue with the Qur'an in answering current problems and being able to accommodate changes and developments of the times. Muhammad Syahrûr did a rereading of the Qur'an with a hermeneutic approach based on a linguistic approach which he called manhaj al-tarikh. The use of the linguistic approach by Syahrûr as the method of the Qur'an cannot be separated from his assumption that the Qur'an has two miraculous sides, namely literary and scientific. The first is understood with a descriptive-significant approach while the second with a historical-scientific approach, both of which lie within the framework of linguistic studies. In terms of inheritance law, Muhammad Syahrûr is of the opinion why in the opinion of commentators, men always get double the share of women, and this is considered an axiom as evidenced by the argument that women lack reason and religion.
\end{abstract}

Keywords: islamic inheritance law, contemporary, hermeneutics

Copyright (c) 2021 Khaerul Hadi.

$\triangle$ Corresponding author: Khaerul Hadi

Email Address : khaerul.ardhian@ui.ac.id 


\section{PENDAHULUAN}

Al-Qur'an merupakan petunjuk dan rahmat bagi sekalian alam, serta mampu membimbing umat islam sebagai pedoman ke jalan yang benar. Namun kenyataanya, untuk mendapatkan petunjuk dan rahmat al-Qur'an bukan pekerjaan yang mudah, dibutuhkan segala upaya intelektual dan metodologi penafsiran yang bisa menyesuaikan dengan perkembangan zaman sebagai upaya penyelesaian problemproblem kontemporer yang ada.

Pada dasarnya metodologi penafsiran untuk menetapkan hukum Islam telah dibentuk oleh ulama-ulama salaf sebagai upaya mereka dalam mendialogkan al-Qur'an dengan konteks pada saat itu. Ketika metodologi itu dibawa ke konteks kekinian, kemampuan untuk mendialogkan al-Qur'an dengan konteks baru tersebut ternyata membutuhkan paradigma baru, sehingga berakibat tidak terselesaikannya permasalahan-permasalahan yang ada. Untuk menjadikan al-Qur'an terus relevan maka membutuhkan metodologi baru yang bisa mengakomodasi perkembangan zaman sehingga al-Qur'an menjadi elastis dan fleksibel.

Dari sini bisa dilihat bahwa kalangan mufasir klasik menganggap bahwa alQur'an secara tekstual adalah normatif, sedangkan para mufasir kontemporer pada umumnya menghindari ungkapan-ungkapan literal teks yang dianggapnya sering menjebak. Para mufasir kontemporer dalam hal ini lebih menekankan kepada aspek yang dalam bahasa Fazlur Rahman disebut dengan-ideal moral (weltanschauung, world view) dari al-Qur'an. Dengan kata lainal-Qur'an tidak dipahami sebagai wahyu Allah yang mati sebagaimana dipahami kebanyakan mufasir klasik, melainkan sebagai tuntutan yang bersifat hidup (the living quran). ${ }^{1}$ Oleh karenanya, para mufasir kontemporer menganggap bahwa dalam memahami al-Qur'an pun tidak cukup hanya dengan mengandalkan ilmu-ilmu alat seperti Nahwu, saraf, balagah, ûsul fiqh, namun juga perlu melibatkan perangkat keilmuan modern lain, seperti sosiologi, antropologi, psikologi, dan lain-lain. Inilah yang dilakukan para mufasir kontemporer dan pendekatan hermeneutik pun akhirnya menjadi pilihan mereka untuk memahami (ulang) ayat-ayat al-Qur'an. ${ }^{2}$

Mengutip pendapat Fazlur Rahman bahwa untuk menjadikan al-Qur'an universal dan fleksibel tidak bisa dipahami secara atomistik melainkan harus dipahami secara komprehensif sehingga bisa menghasilkan suatu hukum yang sesuai dengan perkembangan zaman.Pemahaman seperti ini yang tidak didapatkan dalam penafsiran klasik, para ulama terdahulu terlalu asyik bermain-main dengan kata-kata yang menyebabkan mereka terjebak dalam penafsiran literal-tekstual. Hal ini terjadi karena ketidaktepatan dan ketidaksempurnaan alat-alat yang disebabkan oleh kegersangan metode penafsiran. ${ }^{3}$

Muhammad Syahrûr menawarkan metode tafsir yang setidaknya mampu mereduksi subjektifitas tersebut, dan relatif mampu berlaku adil terhadap tuntutan intelektual dan integritas moral. Lebih dari itu, metode ini diharapkan mampu menyelesaikan persoalan-persoalan umat Islam kontemporer. Muhammad Syahrûr merupakan salah seorang intelektual muslim kontemporer yang menawarkan sebuah metodologi baru untuk menafsirkan, memahami dan menetapkan hukum-hukum dalam al-Qur'an. Dengan metodologi tersebut al-Qur'an yang rasional, sistematis, dan komprehensif bisa menjadi al-Qur'an salih li kulli zaman wa makan. Metodologi tersebut

1 Ali Harb, Kritik Nalar al-Quran, EdisiTerjemahan oleh Faisol Fatawi (Yogyakarta: Lkis, 2003), hlm.21.

2 A. Badowi, Tafsir Feminis: Kajian Perempuan dalam al-Quran dan para Mufasir Kontemporer (Bandung: Nuansa, 2005), hlm. 17.

${ }^{3}$ Sahiron Syamsudin, Hermeneutika dan Hadis (Yogyakarta: Elsaq, 2010), hlm. 70. 
bisa dijadikan upaya untuk mendialogkan al-Qur'an dalam menjawab persoalan kekinian dan mampu mengakomodasi perubahan dan perkembangan zaman.

Dalam mengantisipasi persoalan diatas, Muhammad Syahrûr melakukan pembacaan ulang terhadap al-Qur'an dengan pendekatan hermeneutik yang didasarkan pada pendekatan linguistik yang ia sebut dengan manhaj al-tarikh. Dijadikannya pendekatan linguistik oleh Syahrûr sebagai metode al-Qur'an tak lepas dari asumsinya bahwa al-Qur'an memiliki dua sisi kemukjizatan yakni sastrawi dan ilmiah. Yang pertama dipahami dengan pendekatan deskriptif-signikatif sedangkan yang kedua dengan pendekatan historis-ilmiah yang keduanya terletak pada bingkai studi lingusitik. ${ }^{4}$ Metode ini memberikan pemahaman yang sistematis dan kontekstual, sehingga menghasilkan suatu penafsiran yang tidak terpisah-pisah (atomistik), literalis, dan tekstualis.

Al-Qur'an diturunkan untuk mereformasi permasalahan sosial yang lebih bersifat spesifik, al-Qur'an bertujuan untuk menguatkan bagian-bagian masyarakat yang lemah: orang-orang miskin, anak-anak yatim, kaum wanita, budakbudak, dan orang-orang yang terjerat hutang. Tetapi, untuk memahami reformasireformasi sosial al-Qur'an tersebut, adalah salah jika kita tidak dapat membedakan antara undang-undang yang legal dan perintah-perintah di bidang moral. Setelah memahami perbedaan ini maka kita tidak hanya dapat memahami orientasi yang sesungguhnya dari ajaran al-Qur'an, tetapi kita pun dapat memecahkan masalahmasalah yang rumit, seperti halnya dalam reformasi wanita dalam hal waris dan kesetaraan gender. ${ }^{5}$

Dalam hal hukum waris Muhammad Syahrûr berpandangan mengapa dalam anggapan mufasir, laki-laki selalu mendapat dua kali lipat bagian perempuan, dan dianggap sebagai aksioma yang dibuktikan dengan argumen bahwa perempuan kurang akal dan agama?. Ketika bertanya mengapa Allah mengawali ayat dengan kata laki-laki (żakar) bukan perempuan, mereka menjawab; karena laki-laki lebih unggul dari pada perempuan, maka ia disebut dulu dari pada perempuan. Penyebutan lakilaki lebih dulu juga menunjukan keutamaan tingkat lelaki atas perempuan. Hal ini menunjukan bahwa pihak yang disebut dengan keutamaan tentu jauh lebih tinggi tingkatannya dari pihak yang disebut kehinaan. Perempuan adalah aurat, fitnah dan buruk semua. Para mufasir memperkuat anggapannya dengan hadis-hadis yang disandarkan kepada Nabi.

Menurut Syahrûr laki-laki disebut terlebih dahulu dari perempuan karena posisinya sebagai variable pengikut (tabi'), sedangkan perempuan disebut dengan jumlah satu sampai tak terhingga karena posisinya adalah sebagai variable peubah (mutahawwil). pada kondisi ini satu-satunya kemungkinan yang logis adalah redaksi; li aż-żakari miślu hazzi al-unśyain, karena perempuan adalah dasar dalam pembagian harta waris, dan laki-laki mengikuti ketentuan yang dihasilkannya. Konsep li aż-żakar miślu hazzi al-unśyain adalah kemungkinan pertama dalam pembagian harta warisan (batas hukum pertama dari batas-batas hukum Allah dalam pembagian harta warisan. ${ }^{6}$ Dari sini Muhammad Syahrûr menawarkan konsep hukum waris yang berbeda dari produk-produk penafsiran mufasir klasik dengan menggunakan pendekatan hermenutika.

${ }^{4}$ Muhammad Syahrûr, Metodologi Figh Islam Kontemporer, edisi terjemahan oleh Sahiron Syamsuddin (Yogyakarta: Elsaq Press, 2008), hlm. 17.

${ }^{5}$ Fazlur Rahman, Tema Pokok Al-Quran (Bandung: Pustaka, 1980), hlm. 23.

${ }^{6}$ Syahrûr, Metodologi Figh Islam, hlm. 347. 


\section{Hermeneutika Hukum Islam}

Hukum Islam (Islamic Jurisprudence) merupakan poros dan inti agama Islam. Secara tradisi ke-Islaman, hukum Islam telah menjadi arena untuk mengkaji batasan, dinamika, dan makna hubungan antara Tuhan dan manusia.Hukum Islam merupakan salah satu puncak prestasi peradaban Islam, merupakan khasanah intelektual Islam yang cerdas, komplek, dan sangat kaya.Manifestasi paling nyata dari kenyataan yang menyedihkan dari hukum Islam adalah maraknya otoritarianismedalam diskursus hukum Islam kontemporer.Salah satu ulama kontemporer yang mengkaji dinamika perkembangan hukum Islam dengan pendekatan hermeneutika hukum Islam adalah Khaled Abou El Fadl.

Mengutip pendapat Khaled Abou El Fadl bahwa sebenarnya epistemologi dan premis-premis normatif yangmengarahkan perkembangan dan mengembangkan tradisi hukum Islam klasiksudah tidak ada lagi atau dengan kata lain telah mati. Tradisi hukum Islam klasik yang menjunjung premis-premispembentukan hukum yang antiotoritarianisme, premis-premis serupa tidak lagi diberlakukan dalam tradisi hukum Islam belakangan ini. ${ }^{7}$

Pada posisi ini Abou El Fadl berusaha melahirkan analisis kritis tentang anatomi praktik penafsiran hukum Islam yang bersifat otoriterdengan pendekatan hermeneutik. Abou El Fadl yakin bahwa selama ini metodologi tafsir otoriterakan menggrogoti integritas teks-teks Islam dan meredupkan suaranya serta dapat mengikis daya guna dan kekuatan hukum Islam.

Setelah Abou El Fadl mengidentifikasi anatomi diskursus otoritas teks,mengusûlkan menjunjung otoritas teksdan membatasi otoritarianisme pembaca,yang disebut menggunakan kekuasaan Tuhan untuk membenarkan tindakan sewenang-wenang pembaca dalam memahami dan mengimplementasikan teks.Abou El Fadl mendudukan secara proporsional hubungan antara teks, pengarang, dan pembaca dalam dinamika pergumulan pemikiran hukum Islam.Sikapnya tetap menjunjung tinggi teks al-Qur'an, tapi dia juga mendukung sepenuhnya upaya jujur dan rasional untuk penjelajahan, pengakajian, dan peneladan terhadap al-Qur'an.Jadi menurut Abou El Fadl, al-Qur'an sebagai kalam Tuhan yang suci dan abadi, tidak lantas tertutup atau menutup diri dari kajian, research, konfirmasi dan kritik

\section{METODE PENELITIAN}

Penulis melakukan pengumpulan data dengan cara menelusuri berbagai macam dokumen berupa buku, regulasi dan artikel pada website yang terkait seputar Asuransi Syariah. Hasil penelusuran ditulis dalam bentuk naratif. Studi dokumentasi yang dilakukan penulis seperti pendalaman untuk melakukan kajian dan interpretasi.

\section{HASIL DAN PEMBAHASAN}

Melalui gagasannya mengenai pendekatan hermeneutika hukum islam, Abou El Fadl ingin sepenuhnya menjadikan teks al-Qur'an tidak anti kritik, al-Qur'an sebagai teks suci haruslah terbuka dan tidak anti kritik, sehingga tetap memancarkan pesona integritasnya. Abou El Fadl benar-benar percaya autentisitas al-Qur'an sebagai firmanTuhan yang suci dan abadi, tetapi tidak kemudian memasung dirinya, tetapi secara merdeka dapat melakukan penjelajahan dan pengakjian terhadap al-Qur'an. Maka, untuk membangun keterbukan tersebut, Abou El Fadl berusaha mendudukan hubungan atau relasi antara Teks (text), Pengarang (author) dan Pembaca (reader) secara proporsional. Selain itu perlu juga proses negosiasi antara ketiga-nya, sehingga tidak

${ }^{7}$ Khaled M. Abou El Fadl, Atas Nama Tuhan, Dari Fikih Otoriter ke Fikih Otoratif, terjemahan R.Cecep Lukman Yasin (Jakarta: PT Serambi Ilmu Semesta, 2004), hlm. 1. 
terjadi tragedi otoritarianisme dalam dinamika pergumulan pemikiran hukum Islam. Anatomi Abou El Fadl tentang berbicara atas nama Tuhan, dapat digambarkan pada skema di bawah ini dan proses relasi yang proporsional dapat dijelaskan, sebagai berikut :

Gambar 1.1

Skema Hermeneutika Hukum Islam Abou El Fadl

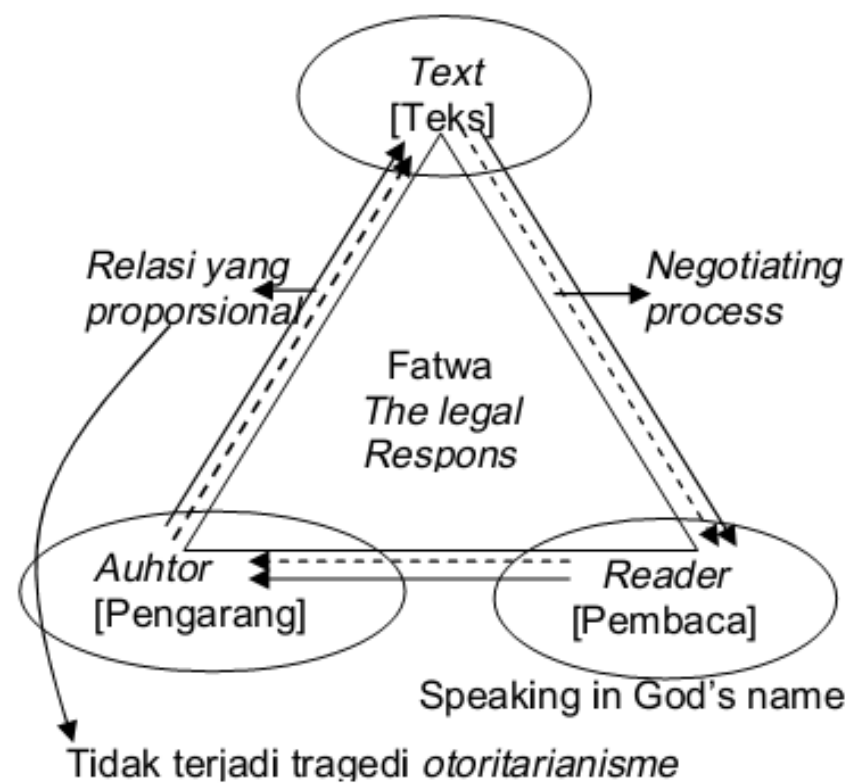

Pertama, teks al-Qur'an sebagai teks tertulis (the written Words) yang abadi, tidak lebih sepeti teks-teks lain yang beredar di tengah pada pembaca. Katakan saja, teks al-Qur'an, telah ditinggalkan pengarangnya (Allah) dan kini telah menjadi miliki publik. ${ }^{8}$ Para pembaca tidak dapat melakukan konfirmasi kepada pengarang (dalam hal ini Allah) terhadap apa yang dikandung dalam teks tersebut. Teks tersebut telah berada di pembaca, maka tidaklah berlebihan jika dikatakan bahwa teks tersebut berdiri sendiri dan telah bergulir secara bebas berada ditangan pembaca, siapapun dapat membaca dan menafsirkannya sesuai dengan maksud, kepentingan,latar belakang sosial dan budaya, bahasa, maupun pola dan model sang pembaca.

Dengan kata lain, ketika pembaca - tanpa melibatkan latar belakang dan ideologinya, akan membiarkan teks berbicara sendiri sesuai dengan tanda dan bahasa yang dimilikinya - maka teks tersebut bersifat otonom dan berdiri sendiri. Dalam situasi seperti ini apabila teks tersebut ketika dipahami - tidak membutukan kehadiran pengarang (author). Namun demikian, tidak membiarkan teks tersebut - apalagi alQur'an atau fatwa keagamaan - berbicara sendiri, tentu akan menggiring teks tersebut menjadi otoriter terhadap pembaca.

Kedua, pengarang (author)secara historis kehadiran suatu teks tidak dapat dipisahkan dari pengarangnya.Ketika seorang pengarang menuliskan teks akan senantiasa bergelut dengan simbol-simbol bahasa yang digunakan. Artinya pengarang telah mewadahi dan memercayakan makna yang dikehendakinya ke dalam simbolsimbol bahasa yang digunakan yang merupakan sebuah media yang dapat dipahami pembaca.Dengan dasar ini, kemudian Abou El Fadl mempertanyakan apakan simbolsimbol bahasa yang digunakan murni merupakan hasil justifikasi pengarangataukah

8Ibid., hlm. 19. 
media itu sendiri yang memformat ulang sebagian atau keseluruhan maksud pengarang dengan memaksa subjektvitaspengarang untuk tunduk pada struktur logika bahasa.

Teks yang telah ditulis pengarang dan pengarang telah memisahkan dirinya dari apa yang dituliskannya, otoritas-nya sebagai pengarang tidak lagi berpengaruh pada teks. Jika teks telah menjadi miliki publik, maka pengarang tidak berhak melakukan intervensi kepada pembaca atau publik dalam kebebasannya melakukan pencarian makna atas teks tersebut.Oleh kerena itu, pemisahan antara pengarang dengan teks sering kali memicu terjadinya reduksi makna atas teks atau sebaliknya. Tetapi pada sisi lain, makna teks semakin mengalami pengkayaan dan bermakna. Hal ini mungkin saja dapat terjadi, bila pengarang dapat diketahui dan logika berpikir, metodologi, konsepserta alur pikirnya Penulis dan pengkaji teks lainnya.Apabila pengarangnya sulit dilacak, serta logika berpikir, metodologi, konsep dan alur berpikirnya tidak dapat diketahui, maka yang terjadi adalah lahirnya konflik baru antara pembaca atas teks yang dibacanya.

Namun demikian, seringkali teks tidak mencerminkan apa yang dimaksud oleh pengarang, bahkan mungkin bertolak belakang dengan maksud pengarang. Bagaimana mungkin pembaca dapat memastikan maksud yang dihendaki pengarang jika tujuan pengarang itu sendiri tidak dapat dipahami oleh pembaca. ${ }^{9}$

Untuk hal ini, Abou El Fadl memberikan pencerahan, khususnya dalam kasus teks-teks yang dianggap suci. Otoritarianisme akan membawa dampak sangat besar sebab otoritas suci yang dikandung teks -yang diandaikan kaum beriman sebagai otoritas Ilahi- dapat dengan mudah dianggap sama dengan otoritarianisme sang penafsir atau pembaca. Sang pengarang al-Qur'an tidak hadir untuk meluruskan makna teks yang ditulis-Nya itu? Tetapi, sang pengarang teks al-Qur'an keterlibatannya dalam menentukan makna atas teks yang dimaksudkannya melalui penafsir-penafsir atau pembaca yang mempunyai komitmen khusus. Atas dasar ini, Abou El Fadl menjelskan bahwa persyaratannya yaitu :(1) kejujuran, (2) sungguhsungguh, (3)pengendalian diri, (4) kemenyeluruhan dengan mempertimbangkan berbagai aspek yang lain, dan (5) rasional yaitu mendahulukan tindakan yang masuk akal.10

Ketiga, pembaca (reader). Kehadiran pembaca dihadapan teks yang bisu menjadikan teks mempunyai makna. Teks telah tersaji dan sang pengarangpun tidak hadir mengawal teksnya di tengah para pembaca. Teks bergulir dengan sendirinnya dan maknanya sangat tergantung pada siapa yang membacanya.Oleh karena itu, Abou El Fadl tidak berupaya untuk menjadi teks (al-Qur'an dan hadis) sebagai sesuatu yang bergulir tanpa pengawalan. Abou El Fadl tidak rela dengan sikap para pembaca yang sewenang-wenang memperkosa teks, apalagi para pembaca mencatut nama Tuhan dan atau menjadikan diri mereka sebagai Tuhan.

Abou El Fadl menganggap sangat problematik tentang persoalan-persoalan fatwa-fatwa keagamaan Islam tentang perempuan yang mengklaim pelarangan perempuan mengunjungi makam suaminya, mengeluarkan suaranya ketika salat dan berdo'a, mengendarai atau mengemudi mobil, berpergian tanpa ditemani laki-laki mahramakan menimbulkan godaan seksual. Fatwa-fatwa tersebut dianggap oleh Abou El Fadl sebagai suatu tindakan yang merendahkan martabat perempuan untuk tidak menyebut "menindas" perempuan yang tidakdapat dibenarkan pada era modern ini. ${ }^{11}$

Abou El Fadl mengatakan fatwa-fatwa tersebut berlindung dibawah teks atau nash yang mengklaim bahwa itulah yang sebenarnya dikehendaki Tuhan. Pertanyaan

\footnotetext{
${ }^{9}$ Ibid., hlm. 14.

${ }^{10}$ Ibid., hlm. 251.

11Ibid., hlm. 382.
} 
yang dikemukakan Abou El Fadl ialah hal apa yang membenarkan atau melahirkan jenis penetapan semacam itu? Jika ingin menjawabnya secara apologetisbahwa budaya adalah pihak yang bertanggung jawab dan penetapan-penetapan tersebut tidak ada kaitannya dengan perintah agama, tetapi hasil dari budaya yang sangat patriarkis. ${ }^{12}$

Abou El Fadl mengatakan bahwa hukum Islam sebagai sebuah epistemologidan metodologipenelitian telah didominasi oleh diskursus otoriter. Otoritarianisme tersebut bukan hanya mencerabut integritas dan kehormatan hukum Islam, tetapi juga akan menghancurkan kekuatan dan dinamika hukum Islam dalam diskursus modern. Sehingga hukum Islam akan menjadi tertutup, kaku, rigid dan tidak mampu disentuh oleh kreativitas dengan dimensi sosiologis-antropologis-psikologis manusia. Abou El Fadl menegaskan bahwa subjektivitas yang selektif dari hermeneutik otoriter melibatkan penyamaan antara "maksud pengarang" dan "maksud pembaca", dengan memandang maksud tekstual dan "otonomi teks"sebagai hal yang bersifat sekunder.

\section{Hermeneutika Hukum Islam Muhammad Syahrûr}

Pada awalnya, secara legal hermeneutika merupakan metode interpretasi teks Bibel, yang digunakan.sebagaialat untuk menjelaskan kandungan Bibel dan digunakan sebagai upayauntuk memahami apa yang dikehendaki Tuhan bagi manusia dalam Bibel. Kemudian hermeneutika mengalami penyempurnaan oleh sarjana-sarjana barat dan mulai digunakan untuk mengkaji berbagai teks, baik itu teks sejarah, sastra, maupun teks-teks lainya.

Dalam pandangan Muhammad Syahrûr, perlu dilakukan pembedaan krusial antara dua bentuk yang berbeda dari wacana agama; pada satu level terdapat realitas ilahiah, yang abadi, kekal, dan absolut. Sementara pada level yang lain terdapat pemahaman manusia terhadap realitas ilahiah tersebut, yaitu tentang sesuatu yang bersifat profan (tidak bersangkutan dengan agama atau tujuan keagamaan), bisa berubah, parsial dan relatif. Karena yang terakhir merupakan produk interaksi dengan paradigma intelektual pada masyarakat dan manusia tertentu, maka ia ada dalam sebuah proses perkembangan dan penyempurnaan yang terus-menerus.

Syahrûr menyadari perbedaan dimensi ilahiah yang absolut dan dimensi manusia yang relatif yang dapat diaplikasikan pada teks itu sendiri.Dia membedakan antara ketetapan "bentuk tekstual" (tabat sighat an-nass) dan "gerakan" dari kandungannya (harakat al-muhtawa).Bentuk tekstual dan linguistik firman Tuhan bersifat ilahiah dan validitasnya kekal abadi, sementara muatan aktualnyadibentuk oleh para pembacanya yang konteksnya selalu berubah dari satu generasi ke genarasi berikutnya, sehingga menuntut sebuah gerakan atau perubahan penafsirannya secara terus menerus. ${ }^{13}$

Ada tiga hal yang perlu diperhatikansebagai kunci dasar dalam mengaplikasikan hermeneutika. Pertama,kainunah yang merupakan deriviasi dari kata kana,berarti berada atau kondisi berada (being). Kedua, sairurah merupakan deriviasi dari kata saara yg bermakna berjalan atau perjalanan sejarah atau kondisi berproses.Ketiga, syairurahyg merupakan deriviasi dari syâra yg bermakna kondisi menjadi (becoming). ${ }^{14}$

${ }^{12}$ Ibid., hlm. 383.

13 Suha Taji-Farouki, Modern Muslim Intellectuals and The Quran (New York: Oxford Press, 2004), hlm. 267-268.

${ }^{14}$ Muhammad Syahrûr, NahwUsûlJadîdah Li al-Figh al- Islami (Damaskus: Ahali, 2000),hlm.

27. 
Ketiga term tersebut selalu menjadi pusat pembahasan dalam filsafat dan landasan ini bagi semua pembahasan mengenai teologi (Tuhan), naturalistik (alam) dan antropologi (manusia), dengan mamandang bahwa kainunah (keberadaan) adalah awal dari sesuatu yang ada, sairurah (proses) adalah gerak perjalanan masa, sedangkan syairurah(menjadi) adalah sesuatu yang menjadi tujuan. Kejumudan terjadi jika hanya mengalami kondisi berada yang ini hanya dimiliki Tuhan dan karena itu Allah berfirman "segala sesuatu pasti akan binasa kecuali Allah" (QS. alQashas: 88).

Disini kita melihat hal yang sangat penting, yaitu adanya keterkaitan antara ketiga istilah tersebut, di mana eksistensi istilah-istilah tersebut terikat satu dengan yang lainnya. Kondisi sairurah (berproses)itu, berarti perjalanan masa, akan tetap hampa (tak berarti) apabila tidak terjadi pada sesuatu yang eksis, bergerak dan terpengaruh oleh perjalanan atau perubahan masa, sehingga atas terpenggaruh perubahan zaman, sesuatu yang telah ada itu berubah menjadi sesuatu yang lain. Kondisi syairurah(menjadi) itu tidak akan terwujud selama tidak adanya sesuatu yang mengalami "kondisi berproses". Semuannya itu mengantarkan kita sampai pada satu keyakinan bahwa tidak ada eksistensi (kondisi berada) tanpa perkembangan, dan tidak ada perkembangan tanpa eksistensi.

Lebih lanjut, tidak semua eksistensi berada pada tiga kondisi tersebut, terkait dengan ini Syahrûr mengklasifikasikanya menjadi tiga;

Pertama, "kondisi berada" dan "kondisi berproses" tanpa "kondisi menjadi", seperti; adanya hari kebangkitan, surga, neraka dan lain-lain. Sebagaimana yang diterangkan dalam QS. al-Kahf: 34-37. Pada level ini, eksistensi bersifat tetap tanpa keberakhiran. Seandainya padanya terjadi proses perjalanan waktu, maka perjalanan waktu itu memiliki pengertian lain yang tidak memuat arti perubahan, pengantian dan perkembangan. Karena semua itu hanya terjadi pada "kondisi menjadi" (Syairurah). ${ }^{15}$

Kedua, "kondisi berada" dan "kondisi menjadi" tanpa "kondisi berproses", eksistensi pada level ini berarti adanya perubahan dari "kondisi berada" menuju "kondisi menjadi" tanpa adanya pergerakan dan perjalanan waktu, seperti halnya cahaya dan hari kiamat. Keduanya "berada" dan "tak berada", eksistensinya hanya memiliki satu bentuk dan kecepatannya yang cepat adalah "keberakhirnya". ${ }^{16}$

Ketiga, "kondisi berproses" dan "kondisi menjadi" tanpa "kondisi berada". Level ini disebut dengan hukum dialektika internal yang juga disebut "negasi dan penegasian terhadap negasi (al-nafy wa anfy al-nafy). Seperti bing bang pada alam semesta adalah peniadaan terhadap sesuatu yang ada sebelumnya, baik sesuatu itu "ada" ataupun "tiada". Hukum dialektika internal adalah prinsip hukum yang menyimpan atau yang mengandung tujuan akhir. ${ }^{17}$

Landasan dasar hermeneutika Syahrûrdi atas mengindikasikan akan adanya anjuran Syahrûr untuk sadar sejarah dalam memahami al-Quran, terutama pada konsep sairurah dan inilah yang mungkin dalam bahasa Amin Abdullah disebut sebagai cara baca historis (qira'ah tarikhiyah) karena bagaimanapun produk tafsir sekaligus metodologinya, juga sebagai eksistensi (kainunah) yang tak lekang oleh perjalanan sejarah (sairurah) yang tentu harus berkembang dan bahkan berubah sesuai dengan kebutuhan dan tuntutan zaman sehingga dalam hal ini proyek metodologi atau perangkat prosedural dalam memahami al-Qur'an sebagai sebuah keharusan yang ini merupakan bagian dari "kondisi berproses" dari perjalanan tafsir sebagai usaha untuk

\footnotetext{
15 Ibid., hlm. 30.

16 Ibid., hlm. 31.

17 Ibid., hlm. 32
} 
membumikan al-Qur'an yang dialektis disatu sisi dan sebelumnya dilain sisi bisa saja telah usang karena telah mengalami "kondisi menjadi".

Kesimpulannya, penafsiran atau interpretasi sebagus apapun sebenarnya hanya merupakan anak dari zamannya yang tentu ada nilai historisitasnya (sairurah) yang perlu dipertimbangkan kembali untuk dikaji kembali.Sehingga dengan hal ini kita bisa membedakan mana Islam dengan esensinya yang hakiki atau Islam dengan muatan historisitasnya yang ikut andil membentuknya sebagai produk penafsiran sehingga tak lepas dari pewarnaan sosio-kultural tertentu yang sektarian (syairurah).Dengan berbekal pemahaman di atas, maka Syahrûr mencetuskan konsep dasar-dasar hermeneutika hukum Islam sebagai syarat yang harus dipenuhi dalam legislasi Islam kontemporer, antara lain ${ }^{18}$ :

a. Bahasa arab harus dipahami sebagai bahasa yang terbebas dari sinonimitas, teks kebahasaan apapun harus dipahami berdasarkan premis-premis logika

b. Para pemegang otoritas hukum harus memiliki pemahaman terhadap dasar-dasar pengetahuan ilmiah pada masa mereka hidup

c. Menguasai hukum-hukum ekonomi dan sosial pada masa mereka hidup

d. Mempertimbangkan produk pemikiran para ilmuwan ilmu-ilmu alam dengan segenap cabang-cabangnya, seperti matematika, kimia, dll

e. Secara teguh berpegang pada prinsip "qiyas syahid ala syaahid" dengan dukungan bukti-bukti materiil obyektif sebelum mengeluarkan keputusan hukum apapun. Dalam hal ini harus bekerjasama dengan para ahli survey atau pengelola data statistik.

f. Jika salah satu faktor mengalami perubahan, khususnya kondisi objektif yang melingkupi peristiwa hukum, maka hukum yang telah diputuskan harus ditinjau ulang.

g. Mempertimbangkan kaidah "jika ada sebuah hadis shahih, saya bersandar padanya" sebagai kaidah yang tidak selalu benar karena keshahihan suatu hadis tidak menjamin pemutlakan pemberlakuannya.

h. Tidak terikat dengan suatu aliran tertentu

i. Mempertimbangkan struktur permukaan (custom) dalam masyarakat sebagai alat kontrol penentu hukum.

j. Sama sekali tidak boleh mengabaikan bahwa dasar legislasi Islam dan kehidupan manusia adalah kebebasan dan kebolehan.

k. Sama sekali tidak boleh mengabaikan bahwa Islam adalah agama yang hanif/fleksibel, maka produk hukumnya apapun yang menghalangi jalannya perkembangan masyarakat dan menentang keadilan relatif harus dihindari tanpa keluar dari batas-batas hukum Allah.

1. Para pemegang otoritas hukum kontemporer wajib berhati-hati dengan dua dasar fiqh yang selama ini diterima secara luas.

\section{Pemikiran Muhammad Syahrûr Mengenai Hukum Waris}

Sebelum memahami lebih dalam mengenai gagasan Syahrûr tentang pewarisan (al-Irś), menurut penulis dipandang perlu untuk memaparkan sedikit tentang gagasan wasiat dalam pandangan Syahrûr. Dalam kajiannya terhadap ayatayat at-Tanzil al-Hakim, Syahrûr menemukan bahwa ayat yang berbicara masalah wasiat ada sepuluh dan tiga ayat yang berbicara masalah pembagian harta warisan. Syahrûr mengungkapkan bahwa dalam empat lokasi pada ayat-ayat waris, Allah SWT telah menetapkan pengutamaan pelaksanaan wasiat dalam pembagian harta warisan (tirkah).

Wasiat adalah salah satu distribusi kekayaan yang dilakukan oleh seseorang

${ }^{18}$ Muhammad Syahrûr, al-Kitâbwa al-Quran: Qira'ah Mu'ashirah (Damaskus: Ahali, 1990), hlm. 583. 
setelah kematiannya untuk diberikan kepada pihak atau kepentingan tertentu dengan ukuran tertentu sesuai dengan keinginan dan pertimbangan pewasiat. ${ }^{19}$ Syahrûr berpendapat; ${ }^{20}$

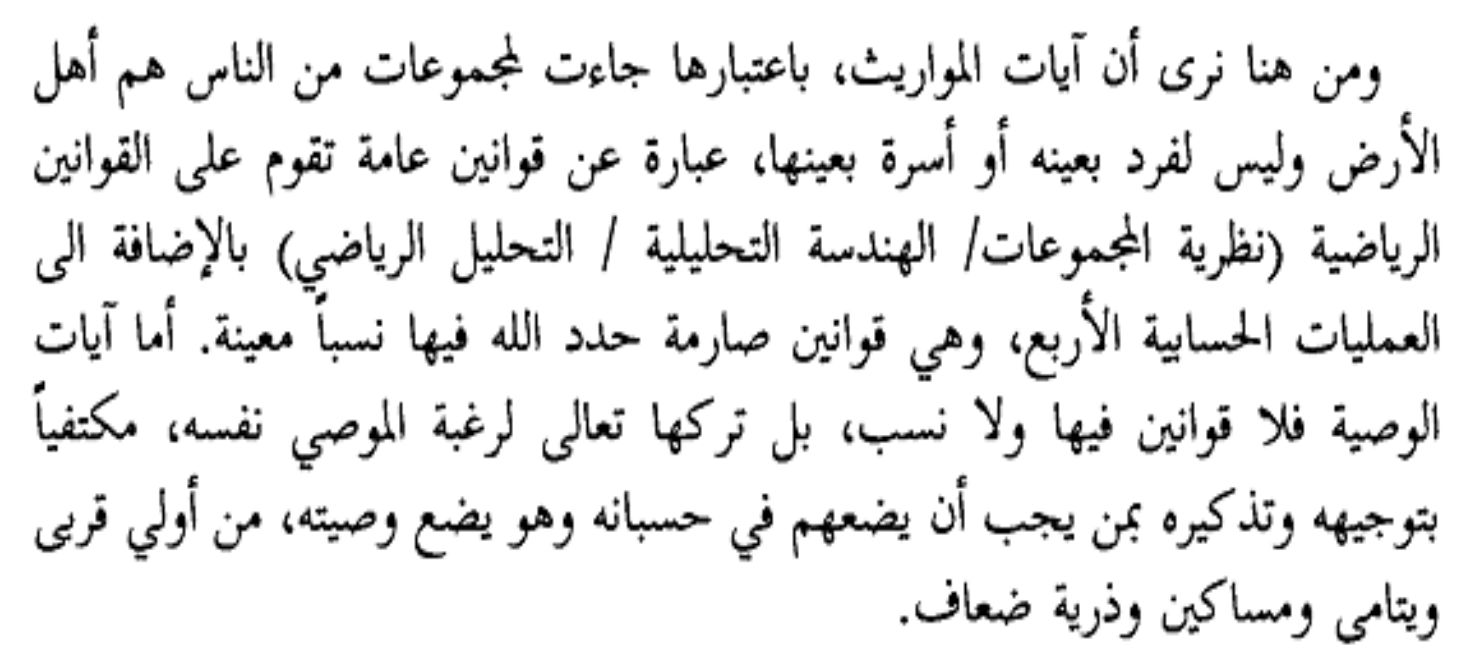

"Dari sini kita melihat bahwa ayat-ayat tentang waris diturunkan dan diberlakukan bagi seluruh manusia secara kolektif yang hidup dimuka bumi, bukan untuk pribadi atau keluarga tertentu. Ayat-ayat waris menggambarkan aturan universal yang ditetapkan berdasarkan aturan matematis (teori himpunan/ teknik analisis/ analisis matematis) dan operasional ilmu hitung (penjumlahan, pengurangan, perkalian, dan pembagian), aturan-aturan tersebut merupakan ketentuan Tuhan yang tetap dan sudah ditentukan. Adapun ayat-ayat wasiat sama sekali tidak mengandung ketentuan hukum ataupun ketentuan pihak keluarga/ keturunan (nasab) yang harus diikuti, karena Allah memberikan keluasan yang sangat lebar kepada manusia untuk berwasiat berdasarkan keinginannya sendiri. Allah cukup memberikan dorongan untuk memberikan prioritas sasaran wasiatnya kepada mereka yang paling berhak menerima dan kekurangan, seperti keluarga dekat, anak-anak yatim, orang-orang miskin dan keturunan yang lemah." 21

Sedangkan pewarisan adalah proses pemindahan harta yang dimiliki seseorang yang sudah meninggal kepada pihak penerima yang jumlah dan ukuran bagian yang diterimanya setelah ditunaikannya wasiat atau jika tidak ada wasiat, maka penentuan pihak penerima, jumlah dan ukuran bagiannya ditentukan dalam mekanisme pembagian warisan. Prioritas utama dalam permasalahan ini terletak pada wasiat, yaitu adakalanya pewaris sudah menentukan wasiat sebelum ia meninggal. Namun, adakalanya pula seseorang yang meninggal dunia tersebut tidak menulis wasiat apapun, maka Allah mengambilalih pembagian harta peninggalan dalam persoalan ini dengan memasukannya dalam mekanisme hukum waris dan menentukan semua pihak yang terlibat di dalamnya baik terkait pihak yang menerima warisan maupun bagian harta yang diterima masing-masing. ${ }^{22}$

Dalam memahami ayat-ayat kewarisan, Muhammad Syahrûr berupaya melakukan pemahaman baru dalam menafsirkan ayat-ayat tersebut. Syahrûr berusaha mengkritik penafsiran konvensional ulama' jumhur terhadap penafsiran ayat-ayat wasiat dan kewarisan sebagai bentuk ketidakpuasannya terhadap penafsiran ayat-ayat

\footnotetext{
${ }^{19}$ Muhammad Syahrûr,Nahw Usûl Jadîdah, hlm. 225.

${ }^{20}$ Ibid.,hlm.225.

${ }^{21}$ Muhammad Shahrur, Metodologi Islam, hlm. 324.

22 Ibid.,hlm.231.
} 
tersebut. Karena dalam penafsiran konvensional tersebut menurut Syahrûr terdapat problem-problem epistemologis dan sosial praktik. Problem epistemologis yang dimaksud adalah bahwa penafsiran konvensional terhadap ayat-ayat waris masih berlaku pada penerapan teori matematika klasik yang terfokus pada proses penjumlahan, pengurangan, perkalian dan pembagian (al-analiyyat al-hisabiyyah alraba'), sedangkan problem sosial politik adalah bahwa tradisi patriakhis dan politik sangat berpengaruh pada penafsiran konvensional. Dengan demikian, perempuan hampir selalu merupakan pihak yang diberlakukan kurang adil. Selain itu, hukum waris konvensional menerapkan perhatiannya pada bagian-bagian individu bukan bagian kelompok.

Oleh karena itu, untuk mengatasi problem epistemologis Syahrûr menawarkan metode baru dalam memahami hukum dan aturan pembagian waris yakni dengan menerapkan ilmu eksakta modern sebagai berikut: Teknik Analisis (al-Hadaras atTahliliyah), Analisis Matematis (at-Tahlil ar-riyadi), Teori Himpunan (al-Majmu'at), dan Konsep Variable Pengikut (at-Tabi', Resultat) dalam matematika yang dapat digambarkan dengan rumus persamaan fungsi berikut:

$$
Y=f(x)
$$

Yang berarti bahwa $\mathrm{x}$ menempati posisi sebagai variabel pe-ubah (mutahawil) dan y sebagai variabel pengikut (tabi'), nilainya tergantung nilai yang dimiliki $x$, sehingga nilai Yang selalu berubah dan berganti mengikuti perubahan yang terjadi pada nilai $x .{ }^{23}$ Dalam hukum waris, Syahrûr menyimbolkan laki-laki dengan (y) sebagai variabel pengikut dan perempuan dengan simbol (x) sebagai variabel pe-ubah. Dalam hal ini, perempuan adalah dasar dalam penghitungan waris, dan bagian laki-laki ditetapkan batasannya setelah bagian perempuan ditetapkan, karena sebagai variabel pengikut (y) nilainya berubah dan bergerak sesuai dengan perubahan bagian perempuan $(\mathrm{x}) \cdot{ }^{24}$

Sementara untuk menghilangkan pengaruh politik dan tradisi, dia berusaha menafsirkan ulang ayat-ayat waris dengan menyoroti beberapa persoalan mengenai penafsiran terhadap ayat-ayat waris yang dilakukan oleh para ahli fiqih, yaitu problem pertama adalah dalam memahami firman Allah "yusikumu Allah". Allah berwasiat ketika manusia tidak berwasiat dan Allah menetapkan dalam wasiatnya aturan, prinsip dan kaidah waris. Hal ini menolak pendapat yang menyatakan bahwa ayat wasiat telah terhapus. ${ }^{25}$

Problem kedua adalah dalam memahami firman Allah "fi awladikum". Mereka berhujjah bahwa anak laki-laki ini menutup hak waris cucu untuk menerima warisan dari kakeknya. ini dari satu sisi, menurutnya para ahli fiqih menganggap bahwa "walad" (bentuk tunggal dari kata "awlad") selalu berarti jenis kelamin laki-laki (żakar). Padahal syarat yang jelas dalam firman Allah yang menunjukkan bahwa yang dimaksud dengan awlad adalah mencakup pengertian lakilaki dan perempuan. ${ }^{26}$

Problem ketiga adalah kaitannya dengan firman Allah "li adz-żakari mitslu hazzi al-unsayayyni". Ini adalah hukum waris dalam kasus yang telah ditentukan secara benar, bukan pengertian sepihak hanya seorang laki-laki dan dua perempuan saja, namun menurut Syahrûr bahwa ahli fiqih menjadikannya sebagai hukum dalam seluruh kasus dan kondisi serta menerapkannya seakan-akan Allah berfirman "li adz-

\footnotetext{
${ }^{23}$ Ibid.,hlm. 235.

${ }^{24}$ Ibid.,hlm. 236.

${ }^{25}$ Ibid.,hlm. 239.

${ }^{26}$ Ibid.
} 
żakari mitslu hazzi al-unsayayyni". Allah menunjukkan bahwa jatah laki-laki dua kali lipat dari jatah perempuan adalah dalam satu kasus saja, yaitu ketika adanya dua perempuan berbanding dengan satu laki-laki, dalam arti bahwa terdapat jumlah objektif (mawdu'i) bukan jumlah hipotesis (iftiradi) untuk menyatakan jumlah satu lakilaki dan dua perempuan. Hal ini berarti bahwa dalam wilayah himpunan jumlah lakilaki adalah dua kali lipat jatah perempuan ketika jatah perempuan dua kali lipat jumlah laki-laki ( 1 laki-laki +2 perempuan, 2 laki-laki +4 perempuan, 3 laki-laki +6 perempuan, dan seterusnya).

Problem keempat adalah dalam memahami firman Allah "fain kunna nisa'an fawqa itsnatayni falahunna śulutsa ma taraka". Para ahli fiqh menganggap bahwa dalam ayat tersebut terdapat pola taqdim (mendahulukan penyebutan sebuah kata yang seharusnya terletak diakhir) dan takhir (mengakhirkan penyebutan yang seharusnya didepan), sehingga menurut mereka kemungkinan susunan kalimat sebenarnya adalah "fain kunna nisa'an itsnatayni fama fawqa fa lahunna śulutsa ma taraka" sehingga menyimpulkan memberikan 2/3 bagian bagi dua anak perempuan. Menurut Syahrûr bahwa yang dimaksud "fawqo itsnatayni"adalah jumlah perempuan tiga atau lebih sampai tak terhingga, dan dijadikan oleh Allah sebagai syarat bagi perempuan dan anak orang yang meninggal agar memperoleh bagian 2/3. Dalilnnya adalah bahwa kalimat persyaratan (as-Syartiyah) diletakkan diawal kalimat dan adanya huruf " $f a$ " yang mengikat jawab kalimat persyaratan tersebut, yaitu dalam firmannya "falahunna".Syahrûr menegaskan bahwa :27
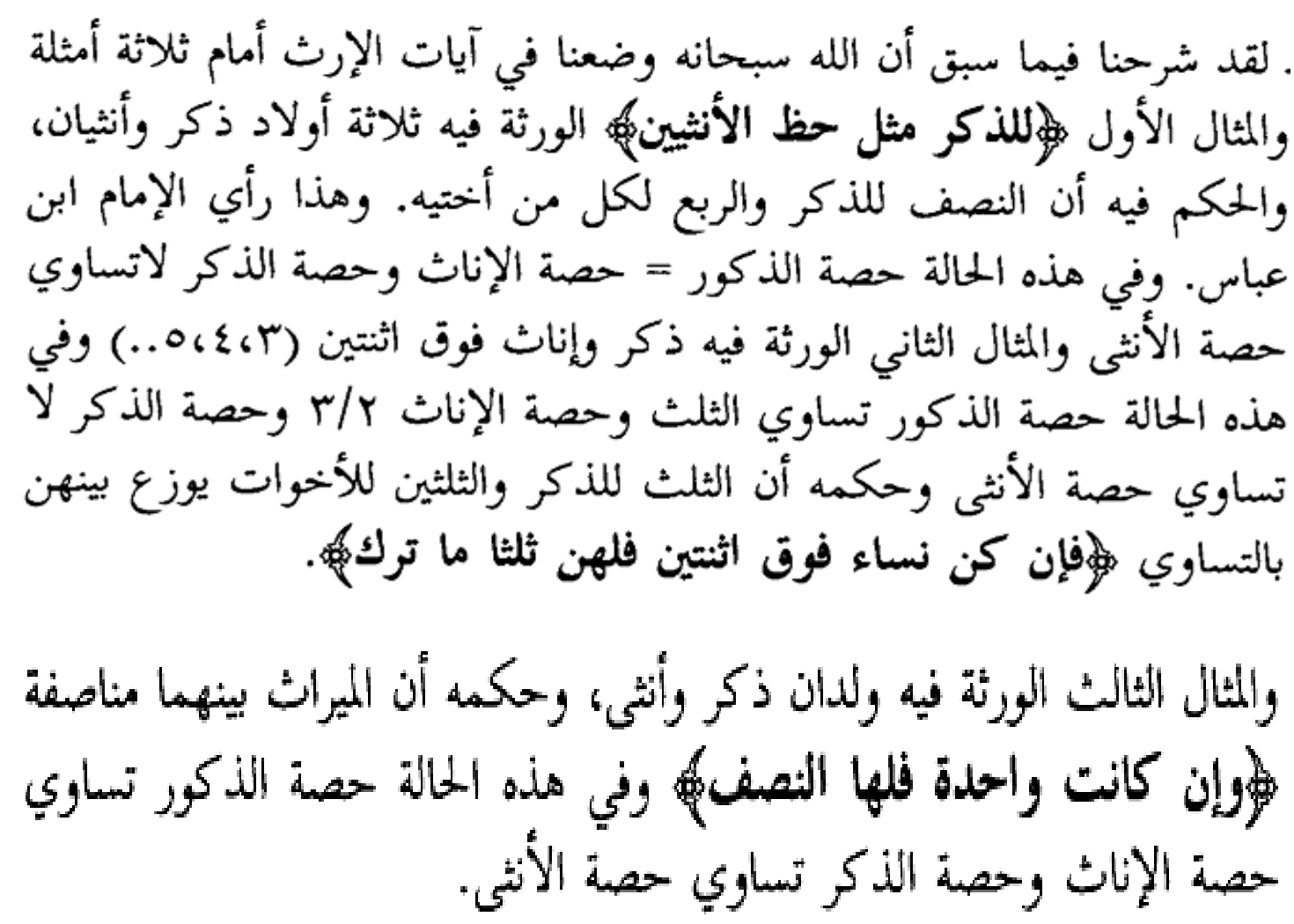

"Allah menetapkan bagi kita dalam ayat-ayat waris tiga macam contoh kasus. Pertama, (li adh-dhakari mithlu hazz al-unthayayni) pewarisnya ada tiga anak, yaitu seorang laki-laki dan dua orang perempuan. Hukumnya adalah setengah bagian bagi anak laki-laki dan seperempat

${ }^{27}$ Ibid., hlm. 243-244. 
bagian bagi setiap saudara perempuannya, ini adalah pendapat Ibn 'Abbas. Dalam kasus ini, secara kolektifjatah kelompok laki-laki sama denga jatah kelompok perempuan. Tetapi jatah setiap anggota dalam kelompok pihak laki-laki tidak sama dengan jatah setiap anggota pada pihak perempuan. Contoh kedua, pewarisnya terdiri dari seorang laki-laki dan tiga perempuan atau lebih. Dalam kasus ini, secara kolektif jatah kelompok laki-laki adalah sepertiga dan jatah kelompok perempuan adalah 2/3. Jatah setiap anggota laki-laki tidak sama dengan jatah setiap anggota perempuan. Hukum pembagiannya adalah sepertiga untuk laki-laki dan dua pertiga untuk saudara perempuan yang dibagikan kepada mereka masing-masing sama rata (fa in kunna nisa'an fawqa ithnatayni falahunna thulutha ma taraka. Contoh ketiga, pewarisnya terdiri dari dua anak, satu laki-laki dan satu perempuan. Hukumnya adalah harta warisan dibagi dua sama rata bagi mereka (wa in kanat wahidatan fa laha an-nisfu). Dalam kasus ini, secara kolektif jatah kelompok laki-laki dan jatah setiap anggota perempuan sama dengan jatah setiap anggota lakilaki. ${ }^{28}$.

\section{KESIMPULAN}

Konsep Hermeneutika Muhammad Syahrûr terkait penafsiran kembali alQuran, menggunakan pendekatan hermeneutik yang didasarkan pada pendekatan linguistik (manhaj al-tarikhi) yang dipengaruhi oleh metode linguistik Abu al-Farisi, Ibnu Jinni, dan Abdul Qadir al-Jurjani, yang menyimpulkan bahwa dalam bahasa Arab tidak dikenal adanya sinonimitas.

Hermeneutika yang dibangun Syahrûr dalam memahami ayat-ayat alQur'an adalah hermeneutika yang berbasis positivisme sehingga mengandaikan tercapainya objektivitas sebagaimana yang dicapai oleh ilmu -ilmu kealaman, yang menjadikan pengalaman, ekspresi dan pemahaman sebagai metode hermeneutis yang menghasilkan objektivitas-positivistik. Dengan demikian menurut penulis hermeneutika Syahrûr belum bisa membebaskan eksistensi manusia dari segala bentuk dominasi subyektivitas penafsiran.

Menurut penulis pada dasarnya dalam metode hermeneutisnya, Syahrûr telah terperangkap pada hegemoni pemikiran positivisme, yaitu pemanfaatan prestasi ilmu pengetahuan modern secara penuh. Hal itu terbukti dalam pandangan Syahrûr tentang teori batasnya (limit), khususnya pada mekanisme penghitungan waris.

Dalam konsep waris Syahrûr, wasiat adalah landasan pertama (prioritas) pengalihan hak milik harta sebagai pembagian harta pusaka secara khusus (kewarisan khusus) yang cakupannya lebih luas, sedangkan waris adalah pengalihan hak milik harta pusaka yang bersifat umum, yang cakupannya telah ditentukan Allah SWT secara eksplisit dalam ayat-ayat waris.

\section{DAFTAR PUSTAKA}

Ali Harb, Kritik Nalar al-Quran, Edisi Terjemahan oleh Faisol Fatawi (Yogyakarta: Lkis, 2003), hlm.21.

A. Badowi, Tafsir Feminis: Kajian Perempuan dalam al-Quran dan para Mufasir Kontemporer (Bandung: Nuansa, 2005), hlm. 17.

Fazlur Rahman, Tema Pokok Al-Quran (Bandung: Pustaka, 1980), hlm. 23.

Muhammad Syahrûr, Metodologi Figh Islam Kontemporer, edisi terjemahan oleh Sahiron Syamsuddin (Yogyakarta: Elsaq Press, 2008), hlm. 17.

Muhammad Syahrûr, Nahw Usîl Jadîdah Li al-Figh al- Islami (Damaskus: Ahali, 2000),hlm. 27.

Muhammad Syahrûr, al-Kitâbwa al-Quran: Qira'ah Mu'ashirah (Damaskus: Ahali, 1990), hlm. 583.

${ }^{28}$ Muhammad Shahrur, Metodologi Figh, hlm. 352. 
Sahiron Syamsudin, Hermeneutika dan Hadis (Yogyakarta: Elsaq, 2010), hlm. 70. Suha Taji-Farouki, Modern Muslim Intellectuals and The Quran (New York: Oxford Press, 2004), hlm. 267-268.

Khaled M. Abou El Fadl, Atas Nama Tuhan, Dari Fikih Otoriter ke Fikih Otoratif, terjemahan R.Cecep Lukman Yasin (Jakarta: PT Serambi Ilmu Semesta, 2004), hlm. 1. 